\title{
Low risk emergencies: integration analysis between primary care and Emergency Care Unit
}

\author{
Urgências de baixo risco: análise da integração entre atenção \\ primária e Unidade de Pronto Atendimento \\ Luana Rodovalho Constantino', Gisele O'Dwyer ${ }^{\mathbf{1}}$, Vera Lucia Barbosa dos Santos ${ }^{\mathbf{1}}$, Marismary \\ Horsth de Seta'
}

DOI: $10.1590 / 0103-11042021131031$

\begin{abstract}
The study aims to analyze the attention given to low risk emergencies in an area of high socioenvironmental vulnerability in Rio de Janeiro, within the scope of the Family Health Strategy and the local Emergency Care Unit. The methodology used relied on a triangulation of data and sources obtained from medical records, direct observation, interviews, and focal groups with managers, workers and users. The service was analyzed according to diagnosis, type of occurrence, and sociodemographic data; the qualitative data was analyzed through thematic analysis, generating the categories: which urgency for which service; territorial issues; access; positive and negative aspects of services. As a result, the Family Health Strategy takes on the function of answering to urgencies. Previous experiences influence the pattern of users' access. Socio-environmental fragility increases demand, stresses the Strategy's programmatic service, and can generate risks by the fast treatment at the Emergency Care Unit, which has been a place of hospitalization, due to the scarcity of hospital beds. The two services work with partial integration. The conclusion shows that the levels of satisfaction with the Family Health Strategy indicated by the population and its centrality to the care networks are enhanced by the accommodation of urgencies.
\end{abstract}

KEYWORDS Primary Health Care. Emergency. Health services. Health care needs and demands.

RESUMO O estudo objetivou analisar a atenção prestada às urgências de baixo risco em área metropolitana de alta vulnerabilidade socioambiental na cidade do Rio de Janeiro, no âmbito da Estratégia Saúde da Família e da Unidade de Pronto Atendimento local. A metodologia utilizou triangulação de dados obtidos em prontuários, observação direta, entrevistas e grupos focais com gestores, trabalhadores e usuários (108 participantes). Analisaram-se os atendimentos segundo diagnóstico, tipo e horário de ocorrência e dados sociodemográficos; os dados qualitativos, mediante análise temática, geraram as categorias: que urgência para que serviço; questões territoriais; acesso; aspectos positivos e negativos dos serviços. Como resultado, a Estratégia Saúde da Família assume a função de atender às urgências segundo dados de produção. Experiências anteriores influenciam o padrão de acesso de usuários. A fragilidade socioambiental incrementa a demanda, tensiona o atendimento programático da Estratégia e pode gerar riscos pelo atendimento rápido na Unidade de Pronto Atendimento, que tem funcionado como lugar de internação, pela escassez de leitos em hospitais. Os dois tipos de serviços funcionam parcialmente integrados. Conclui-se que o nível de satisfação com a Estratégia Saúde da Família destacado pela população e a centralidade da Estratégia para as redes assistenciais são potencializados pelo acolhimento às urgências.

1 Fundação Oswaldo Cruz (Fiocruz), Escola Nacional de Saúde Pública Sergio Arouca (Ensp) - Rio de Janeiro (RJ), Brasil. Irconstantino@gmail.com
PALAVRAS-CHAVE Atenção Primária à Saúde. Emergência. Serviços de saúde. Necessidades e demandas de serviços de saúde. 


\section{Introduction}

With the development of the Unified Health System (SUS), there was a considerable expansion of the Primary Health Care (PHC) service, with positive impacts on the health of Brazilians ${ }^{1}$. Another achievement of the SUS, the emergency policy, proposes a network that articulates services at different levels of care to ensure, in a timely manner, full access to users.

The PHC service is the preferred gateway to the health system, being responsible for solving low-risk emergencies and stabilizing severe cases until transfer to a more complex unit. The Emergency Care Units (ECU), a component of the emergency policy implemented in 2008, act as intermediaries between the $\mathrm{PHC}$ and the hospitals and serve at least 50 thousand inhabitants.

The effective participation of the PHC in emergency care, taking responsibility for the first care, can expand access to emergencies ${ }^{2}$. However, there is an overload of low-risk care in the ECU that could be solved by the $\mathrm{PHC}^{3,4}$, which, in turn, is not always able to accommodate emergencies due to the priority of other tasks and the lack of qualification and adequate structure ${ }^{4}$.

At $\mathrm{PHC}$, the distinction between appointments is often made only in Scheduled Demand (DP) which consists of appointments through prior appointments, as well as Spontaneous Demand (DE), which are unscheduled appointments.

The dual role of ECU and PHC in emergency care justifies the analysis of access, supply and quality of use of these services, especially if they comprise a local assistance network under a single management.

Incorporating the vision of managers, health professionals and service users, focusing attention on care for DE and low-risk emergencies, this article analyzes the care provided in an area of high socio-environmental vulnerability. This vulnerability of the territory is expressed in the living conditions of its populations (low income and low social protection) who live in areas of environmental risk, on the banks of degraded rivers ${ }^{5}$. With approximately 46 thousand inhabitants, the territory has an estimated PHC coverage of $100 \%$ of the population through two units of the Family Health Strategy (FHS), which total 13 teams, and has an ECU III adjacent to one of the units.

\section{Material and methods}

The study was carried out with the triangulation of data and sources on the care provided by the FHS and the ECU, which articulates secondary data on the use of services with primary data produced in interviews, focus groups and observation. In addition, in the data analysis, there was a triangulation of investigators, as there were four investigators who contributed with their perspectives, reflections and interpretations ${ }^{6}$.

In this research, the term low-risk emergencies designates the universe of cases classified as green and blue, according to the Manchester classification, which operates by associating the emergency situation with the waiting time, and is represented by colors: red (emergency / $0 \mathrm{~min}$ ), orange (very urgent / $10 \mathrm{~min}$ ), yellow (urgent / $60 \mathrm{~min}$ ), green (little urgent / 120 $\mathrm{min}$ ) and blue (not urgent $/ 240 \mathrm{~min})^{7}$.

Initially, secondary data obtained from the electronic medical records used in the FHS and ECU were analyzed. The patients ere characterized by age, sex, diagnosis and time and type of demand (DP and DE) to identify low-risk emergencies in the two services.

FHS assistance corresponds to the sum of assistance provided by the two units in the area. For the ECU, only those originating from the region under study performed during the working hours of the FHS were computed. The DE characterized as administrative (rescheduling appointments, changing prescriptions, etc.) were excluded.

The reason for the consultation (main complaint) in the FHS and the ECU was 
also analyzed considering the International Classification of Diseases (ICD). The 20 most recorded diagnoses were organized by disease groups, according to the chapters of the ICD 10. Absolute frequencies were calculated according to sex, age group, risk classification and most prevalent diseases.

In another step, a field research was carried out, which included: 1) observation of care at the three health units, totaling 120 hours of observation on weekdays, with a field journal; 2) interviews and focus groups.

Table 1. Interviews and focus groups conducted by number and type of respondent and length of field

\begin{tabular}{|c|c|c|c|}
\hline Technique used & $\begin{array}{l}\text { Duration of each } \\
\text { technique }\end{array}$ & Type of participants & Total \\
\hline \multirow[t]{3}{*}{ Interview } & 60 minutes & On-call physicians from ECU & 5 \\
\hline & & On-call nurses from ECU & 5 \\
\hline & & $\begin{array}{l}\text { Managers and Technical Managers (physicians and nurses) } \\
\text { from ECU and FHS }\end{array}$ & 9 \\
\hline \multirow[t]{3}{*}{ Focus group } & 90 minutes & Physicians and nurses FHS & 32 \\
\hline & & ACS FHS & 37 \\
\hline & & Users & 20 \\
\hline \multicolumn{2}{|c|}{ Total study participants } & & 108 \\
\hline
\end{tabular}

Source: Self elaborated.

The scripts for the interview and focus groups covered questions on: type of emergency serviced at the unit; ease and difficulties for low-risk emergency care in each type of unit; integration between services; and strategies to better meet demand. Users were asked about what they understood as urgency; when and what are the benefits of seeking out the ECU and/or FHS, and on difficulties in accessing care.

The following participated in the research: coordinators and technical managers, identified as managers $(\mathrm{G})$; doctors and nurses, as professionals with higher education (PS); Community Health Agents (ACS); and users (U). The origin of top-level managers and professionals, whether FHS or ECU, has been identified.

The triangulation carried out in the analysis covered: data, sources and investigators, as per the previous record. Thematic analysis ${ }^{8}$ was used for qualitative analysis of the field material, the result of which dialogued with the quantitative data submitted to descriptive statistical analysis.
The research was approved by the Certificate of Presentation for Ethical Appreciation of the Sergio Arouca National School of Public Health and the Municipal Health Department of Rio de Janeiro, numbers 81927618.3.0000.5240 and 71283317.8.3001.5279.

\section{Results}

The results are organized into information about care, observation in the services and according to the analytical categories that emerged from the thematic analysis, consisting of: what urgency for which service; access; territorial issues; positive aspects of services; and negative aspects of the service.

\section{Information about care}

At the FHS, in 2017, 39,135 consultations were carried out, $76.9 \%$ for DE $(30,107)$ and $23.1 \%$ for DP (graph 1). 
Graph 1. Family Health Strategy services according to type of demand and month of occurrence, 2017

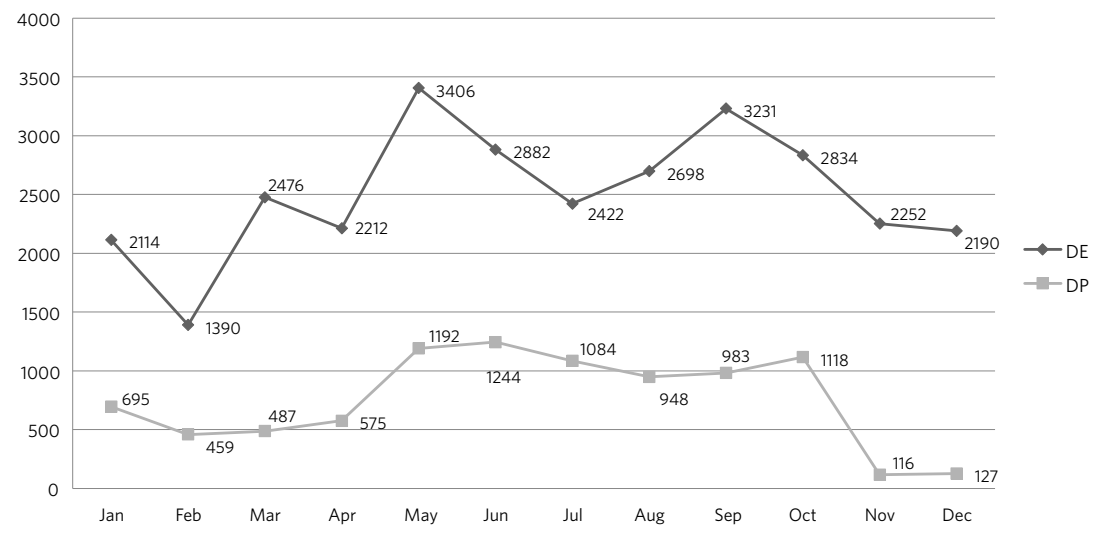

Source: Self elaborated.

At the ECU, in 2017, from 8 am to $5 \mathrm{pm}$, there were 6,206 assistances to users living in the studied district, distributed according to the degree of risk in: red (0.4\%), yellow (17.4\%), green $(82 \%)$ and blue $(0.2 \%)$.

Graph 2. Low-risk emergency care according to type of unit and month of occurrence, 2017

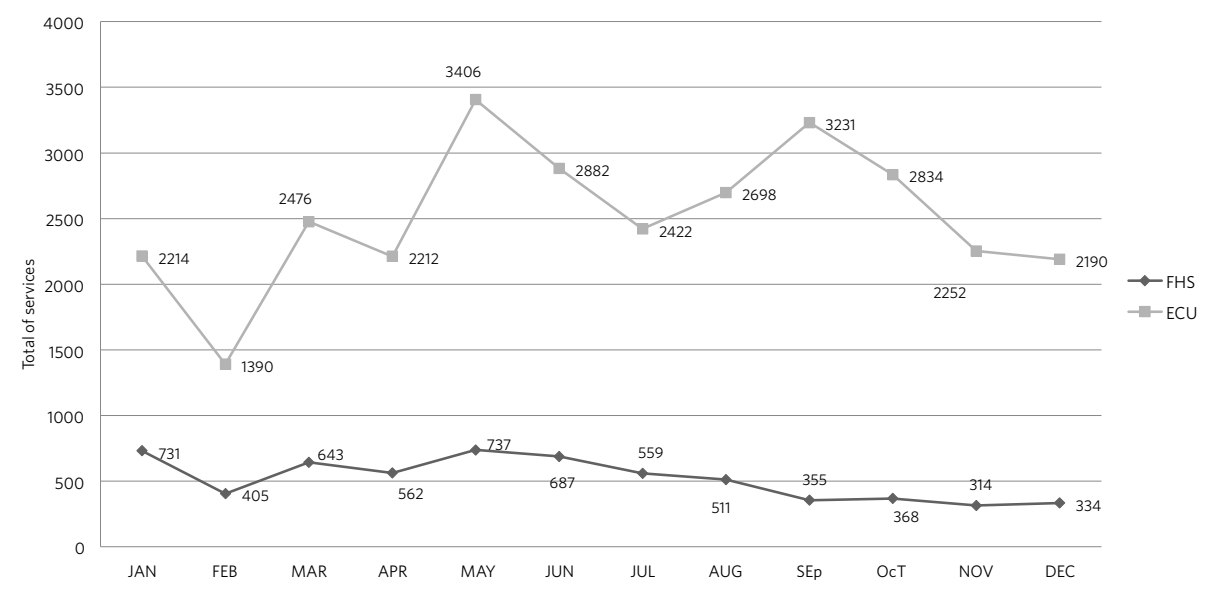

Source: Self elaborated.

With regard to gender, females predominated in the DE visits at the FHS (70\%). In ECU, there was no significant difference in relation to sex.

Regarding the age distribution of care, it was observed that, in the ECU, 65\% $(n=3,315)$ were adults, followed by children with $21 \%$
( $n=1,050)$, elderly with $8 \%(n=409)$ and adolescents with $6 \%(\mathrm{n}=328)$. In the FHS, $63 \%$ were adults ( $\mathrm{n}=9043) ; 18 \%$, elderly $(\mathrm{n}=5,583)$; $14 \%$, children $(n=4211)$; and $4 \%(n=1270)$, adolescents.

Infectious and parasitic, endocrine and metabolic diseases and circulatory system 
diseases were frequent in the PHC clinic. On the other hand, diseases of the respiratory system appeared in both types of service. In ECU, there is a high number of non-specific diagnoses. In the ECU, the volume of musculoskeletal diseases was evidenced, especially the complaints of pain and a high number of non-specific diagnoses (table 2).

Table 2. Main diagnoses recorded in spontaneous demand/low-risk emergencies in the analyzed units

\begin{tabular}{|c|c|c|c|c|c|c|}
\hline \multirow[b]{2}{*}{ Disease group } & \multicolumn{3}{|l|}{ FHS } & \multicolumn{3}{|l|}{ ECU } \\
\hline & ICD & n. of records & Total & ICD & n. of records & Total \\
\hline $\begin{array}{l}\text { I. Certain infectious and } \\
\text { parasitic diseases }\end{array}$ & $\begin{array}{l}\text { A09- Other gastroenteritis and colitis of infec- } \\
\text { tious and unspecified origin } \\
\text { A59- Urogenital trichomoniasis } \\
\text { B37- Candidal stomatitis } \\
\text { B86- Scabies } \\
\text { B359- Dermatophytosis, unspecified } \\
\text { A15- Tuberculosis of lung } \\
\text { B309- Viral conjunctivitis, unspecified }\end{array}$ & $\begin{array}{l}1,452 \\
746 \\
706 \\
704 \\
574 \\
507 \\
507\end{array}$ & 5,196 & * & * & * \\
\hline $\begin{array}{l}\text { IV. Endocrine, nutritional } \\
\text { and metabolic diseases }\end{array}$ & $\begin{array}{l}\text { E119- Type } 2 \text { diabetes mellitus without complica- } \\
\text { tions } \\
\text { E109- Type } 1 \text { diabetes mellitus without complica- } \\
\text { tions } \\
\text { E66- Overweight and obesity } \\
\text { E39- Endocrine disorder, unspecified }\end{array}$ & $\begin{array}{l}2,189 \\
806 \\
623 \\
308\end{array}$ & 3,926 & * & * & * \\
\hline $\begin{array}{l}\text { IX. Diseases of the circu- } \\
\text { latory system }\end{array}$ & I10- Essential (primary) hypertension & 3,114 & 3,114 & * & * & * \\
\hline $\begin{array}{l}\text { X. Diseases of the respi- } \\
\text { ratory system }\end{array}$ & J00- Acute nasopharyngitis [common cold] & 695 & 695 & J00 & 269 & 269 \\
\hline $\begin{array}{l}\text { XIII. Diseases of the } \\
\text { musculoskeletal system } \\
\text { and connective tissue }\end{array}$ & * & * & * & $\begin{array}{l}\text { M791- Myalgia } \\
\text { M545- Low back } \\
\text { pain }\end{array}$ & $\begin{array}{l}556 \\
186\end{array}$ & 742 \\
\hline $\begin{array}{l}\text { XVIII. Symptoms, signs } \\
\text { and abnormal clinical } \\
\text { and laboratory findings }\end{array}$ & * & * & * & R05-Cough & 425 & 675 \\
\hline Other ICD records & & & 17,288 & & & 3,031 \\
\hline Total spontaneous deman & d services / Green and Blue & & 30,107 & - & & 5,102 \\
\hline
\end{tabular}

Source: Self elaborated.

Note: The use of '*' designates values lower than 150 appointments that were counted as 'other ICD records'.

\section{Observation in the services}

In the ECU waiting room, most users did not understand the organization of care by risk classification and there were conflicts when those classified as green waited, regardless of the order of arrival.
In the two FHS clinics, there were users waiting for the opening time, generating a daily queue. The first care for $\mathrm{DE}$ is the responsibility of the ACS and is organized according to the reference team. Nursing technicians and nurses give support at user reception. Furthermore, the main access criterion was the order of arrival. 
The FHS professionals were receptive and affectionate, valuing the demands. Special attention was given to priority groups, such as children under 5 years old, pregnant women, postpartum women and users with tuberculosis. Professionals and users knew each other by name, evidencing the established bond.

The first question asked by users was whether 'there was a doctor to see on the day'. Physicians perform, in addition to care, home visits and group activities. Eventually, users do not accept being seen by nurses in the absence of the doctor.

There is no standard to match the care provided to DE and DP. Users were serviced in an alternating manner between DE and DP.

One of the clinics worked closer to the 'advanced access' methodology, which provides care preferably within 24 hours, whether on an urgent or routine demand 9 . The delay for medical care was up to three hours. During the study, there was a strike by professionals, during which attendances were reduced to $30 \%$. During the strike, the waiting room was a space for discussion with the population about the problems faced in the health area.

Both types of service have a structure for emergency care.

\section{Which urgency for which service}

Managers agree that the best place to seek service for low-risk emergencies is the FHS and that the ECU should only attend to them outside of PHC's opening hours. However, they think it is legitimate for the population to access the preferred service.

Professionals recognize that low-risk emergencies should be attended to at the PHC due to the possibility of monitoring the user, however, some green services could be shared with the ECU: "I think there is a way to share the green" (PS-ECU). Only one medical professional defended that all low-risk care must be exclusively attended by the PHC: "Neither blue nor green should be from the ECU, it would be up to us to assist" (PS-FHS).
One doctor pointed out that, in the face of more serious clinical situations, it is clear to users where they should go (to ECU and/ or hospitals), however, in low-risk urgent matters, the criterion that defines the choice between ECU and FHS is the ease of access:

If it's trauma or an accident, it's clear to him that it's for ECU, but if he feels headache, vomiting, hypertensive crisis, asthma, they want to be seen where it's closest. (PS-FHS).

Managers are concerned about the population's difficulty in using the services properly in urgent demands, in addition to the lack of clarification on the part of the professionals responsible for the selection, who are not prepared to guide users. Health professionals expressed that, in certain situations, they themselves are in doubt about defining the role of ECU and FHS, confusing the user:

In fact, in some day-to-day situations we are also confused regarding what must be attended to at the ECU and what must be attended to at the FHS. (PS-FHS).

Saying exactly what is for the ECU and what is for the FHS is a question that needs further thought. (PS-FHS).

I think it's the doctors' lack of concern to provide more guidance, because you [user] don't know what to look for, so we don't have a better position. (U).

Users support the technical definition of urgency:

Urgent care is when the person is really sick, about to die. A completely injured person, gunshot, beginning of a heart attack, right? A child with shortness of breath is a care with a risk. (U).

For users, both the FHS and the ECU must attend to small emergencies, the main difference being the opening hours: "At the ECU 
when the clinic [FHS] is closed. The ECU doctor said, I'm going to give you medicine, but look for your doctor" (U).

However, they recognize that eventually the clinic (FHS) is not seen as a place of emergency care:

The Family Clinic is more monitoring of pregnant women, with a chronic disease to be treated. The difference between them is this, the Family Clinic provides treatment and the other [UPA] is more urgent. (U).

\section{Territorial issues}

For professionals, poverty, violence and lack of access to other social resources produce demands:

You have social determinants that lead the population to seek more the emergency [...] you have a population in financial difficulty, which has the worst possible employment relationship, so this population does not go to an informative group, they cannot miss work to go to the doctor, they try to solve their life in the emergency room [...] It will optimize the time. (ACS).

We work with an extremely vulnerable population, we stay with teams inflated with users. (PS-FHS).

The issue of the vulnerability of the territory was present in the statements of professionals and most managers as a contributing factor to service overload. The reality of the precariousness of labor relations among the population is pointed out as a driver of their preference for ECU to optimize time, by providing access to satisfy their demands for blood and imaging tests, which are not always prescribed.

The number of people registered per team, higher than in other universal systems, is seen as a major obstacle, especially due to the social fragility of the territory's population:
But it's this issue of us working with a much larger number of clients than the average of countries that work with primary care, it's certainly a bottleneck. We work with a very vulnerable population; they have a great need for access to the Health Service, including for things that are not strictly biological. It's a challenge, the math is always off. (PS-FHS).

Events, such as shootings, occasionally close family health clinics, as well as floods in periods of heavy rain, which flood homes, causing material damage:

We have a very sick population, due to all the violence, too. On the riverbank, people who lost everything, it's very ratty, we're going to start having leptospirosis. There are people who are hungry, without sewage, without electricity, without water, without anything, they have lost documents, medicines, food. (PS-FHS).

Many professionals highlighted violence in the territory as a limiting factor for work, whether in the ECU or FHS, with frequent confrontations between police and drug dealers using firearms, as well as the presence of drug trafficking close to the unit: "there is trafficking, there are shots, which makes it all more complicated. And, sometimes, it is difficult to access the unit, professionals and users" (PS-ECU).

The secure access protocol, with criteria for closing family clinics when there is a shooting, increases demand, putting pressure on ECU care:

The FHS is restricted and closes the service, where do those who had an appointment go to? The user leaves that door and enters our ECU with a sore throat, itching, pediculosis, in addition to the ones that come daily, which come from the Rio de Janeiro region or from another area with insufficient FHS coverage. (G-ECU).

An FHS manager says that the user approach in the ECU must consider social 
fragility. The use of risk classification as an exclusive criterion for care at the ECU, valuing only symptoms, implies denying care:

Knowing about all the vulnerability of the territory, many users resort there, because that's what they have. And ends up denying service to a user who deserves that service. (G-FHS).

Some ECU managers pointed out conflicts with the population. Users would be immediatist, careless with themselves, disguised and too settled:

The user, he has that expectation of immediacy, that 'hospital-centric' thing. The user feels bad, 'I'm going to look for the ECU', he doesn't try to monitor his hypertension and diabetes beforehand. (G-ECU).

People have already learned what to say at the risk classification door and when it arrives at the doctor it is not what was said. (G-ECU).

I think there is a change in the question of culture. Sometimes there are many users who look here [ECU] simply for convenience because it will take a long time for the service there [FHS], so they come to the ECU for anything. (G-ECU).

The FHS professionals highlight the user's low educational level, which makes it difficult to follow the FHS, and the absence of a common medical record:

The level of education of users, in most cases, is very low. They don't really know what motivated the service, what the behavior of colleagues at the ECU were, making it a little difficult for the FHS people to follow up. (G-FHS).

\section{Access}

Access by DE at FHS is guaranteed on a daily basis, although there may eventually be some restriction due to service capacity or the autonomy with which the teams work:
I don't know if there are teams that, when users arrive in the afternoon, say: why didn't you come in the morning? Demand time is at 8 am to be able to fit. (G-FHS).

The use of 'advanced access' helps in the compatibility of DE/DP, and the service takes place on the same day: "we see that the more you open the door and make less schedules, the more you guarantee access"(PS-FHS). However, difficulties in this compatibility were pointed out: "There are scheduled and sometimes it may be that something cannot be fitted on that same day" (G-FHS).

As the FHS is strained by DE, access to a higher quality consultation was questioned:

We are not able to do health promotion and prevention, we only work with care, care... one after the other and what is proposed we really cannot do. This is very bad. (PS-FHS).

Some professionals would even like to absorb more ED, however, they feel overwhelmed due to the size of the enrolled population of the teams:

[...] ideally I would like to meet all the demands of the enrolled population in my area, but on the day-to-day we see that it is not possible because we are overloaded. Maybe if we had 1000, 1500 users we would have enough space to meet everyone who needs it. (PS-FHS).

At FHS, there is a concern with optimizing consultations and approaching the user in the best possible way, as users with repressed demands use the DE to solve problems beyond the current complaint. Thus, it is possible to identify that, even with the large volume of care, they seek to address more than just the complaints of users:

The consultation is different, everything is more detailed, not just the case: are you in pain? He gives the pain medication; wants to know about the family, what is happening? Why this pain arrived? It takes longer. (ACS). 
The complaint is a chronic headache or a fever and when he is in the consulting room he discusses other issues and then he leaves with a referral. Then from a DE consultation he makes a full consultation. (ACS).

One doctor highlighted that, despite the difficulties, the professional committed to the purpose of the FHS can seek to include prevention/promotion actions in the care provided to $\mathrm{DE}$, since the user is in the unit:

The biggest challenge is to be able to create opportunities and make prevention, promotion with spontaneous demand users. In the middle of the service: do you already have a mammogram? It's time. Can I order? And you end up providing opportunities. (PS-FHS).

If there is an indication of hospitalization, the form of access provided for the FHS is to request a vacancy through the city's regulation system: "We regulate the user, it's a little bureaucratic because you need to call, send an e-mail, confirm, and it can only be doctor" (G-FHS).

The local ECU is the main destination for users who are hospitalized: "In 90\% of cases, the vacancy goes to the ECU next door. No need for an ambulance, just wait, it's great!" (G-FHS).

When the user needs more complex technology for emergency care, if he is in the clinic adjacent to the ECU, FHS uses, without barriers, the resources of the ECU.

It is possible to monitor whether the ambulance has been called and where the user will be taken while they are waiting: "I stay with them after hours, I talk about the network's difficulties, I share the situations" (G-FHS).

Although it is somewhat easier for the user to be transferred from the FHS to the ECU, this sending is questioned since, when requesting admission, the user is expected to access the hospital bed:
We need a hospital, but they send it to the ECU and it becomes a snowball because the ECU cannot make a diagnosis, it stays under observation and leaves. (G-FHS).

The bottleneck for the bed in the ECU has repercussions on the FHS:

We see a difficulty in the ICU beds, there is a very high demand. In 2013, we took users out more easily, we had a shorter length of stay. Now I can't effectively transfer to the hospital; in an average of 4, 5 days I discharge around $50 \%$ of my movement. (G-ECU).

[...] very bad and disappointing for the professional to see that the user didn't go to the hospital and that the ECU discharged, and the user will return the next day or two days from now. It is exhausting for the professional, for the user and unfortunately there is less and less bed available. (G-FHS).

ECU professionals identify the excess of low-risk care as an access problem: "There are really few emergencies. We provide primary care" (PS-ECU).

On the other hand, FHS managers complain that there is no formal reference to access the service of its users who left the ECU. The medical record could be an element of integration and continuity of care.

For the user, the choice of each type of equipment is determined by the bond and the most humanized service (FHS) and by the speed of service and access to exams (ECU):

We have rights both at the Clinic and at the ECU. At the clinic, sometimes there is no vacancy for care, but they are always fitting in and their care is always better. (U).

The targeting of the ECU's low-risk user to the FHS is not free from conflicts with the user, who seeks to ensure their service at the ECU:

You have a gateway, you have the doctor there to 
solve the problem. You answer, but make a referral. The problem is that with this the user creates an addiction. It is much easier for him to arrive at the ECU with the door open and be attended to soon, than to become loyal to the PHC. (G-ECU).

A conflict persists about the opportune place for the service, generated by the service itself, which expels the user from the PHC and ECU. Although not prevalent in the studied place, the pilgrimage for care is still a sign of urgent care:

I go to ECU in case of fever. Then they look at me and refer me to the Family Clinic. Then the Family Clinic sends me back to the ECU. So, it's not possible! Then I stay at home. Then I take money and go to Hospital Salgado Filho, where they attend to me. (U).

And when the person is feeling very ill, when they arrive at a place and are not attended to and have to run to another place? (U).

\section{Positive aspects of services}

The biggest advantage of the ECU, from the point of view of emergency care, is the qualification of professionals and the capacity of material resources, such as exams and XR:

At ECU it is easier because of the qualification, there is a back room with equipment that will not be available at the FHS. (G-ECU).

When he arrives here with high blood pressure, I think he will have a much better service than there [at FHS]. (PS-ECU).

The management of FHS also considers that it has the structure and resources to meet spontaneous demands. It is positive that users have the habit of looking for the FHS for emergency care, considered the best place for the bond and continuity of care: "There is continuity of care, there is the accompanying physician, he knows his history, a longitudinal care" (G-FHS).

Users reported a high level satisfaction with the work of the FHS:

I already arrived with a pressure of 22 and I was well received. Nobody frowns at me. (U).

I have been cared for here by the doctors with love, affection, kisses and hugs, and the nurses too. (U).

For FHS professionals, the possibility of monitoring the patient provides technical quality to the care and prevents iatrogenic events:

We realize that, by directing the patient to return for follow-up, the degree of hyperintervention and even iatrogenics is also reduced. Between a question whether it is a bacterial or viral infection, I can ask him to return in one or two days. And if he doesn't return, I can go get him. (PS-FHS).

For FHS managers, proximity and a good relationship with the ECU are advantages: "Having a little break of 5 minutes between one user and another and knowing how your user is hospitalized in the ECU" (G-FHS).

The interaction between the ECU and the FHS was identified as positive by the ECU managers:

The benefit is to have feedback, from the clinic to the ECU and from users under observation, who are from the territory and the team doctor comes to check on. (G-ECU).

However, there was a divergence in judging positively the interaction between the ECU and the FHS:

The relationship is complicated. We sometimes arrive to report a case and we are seen as a doctor of the Unit that doesn't know anything and who is taking a case that is not urgent. (PS-FHS). 
However, despite the divergences, the recognition of social fragility and the ability of the $\mathrm{PHC}$ to accommodate the $\mathrm{DE}$, treating patients with completeness, were positively identified.

\section{Negative aspects of the service}

For managers, in the years 2017 and 2018, there were cuts in funding and other threats to the SUS. At PHC, there was a strike, increasing the difficulty for the ECU: "Political moment, moment of leaving, don't go, get fired or not. It interferes" (G-ECU).

The form of care of the ECU, centered on the complaint, was seen as negative:

At ECU, every time you come, you are assisted by a different professional, it is always an on-call attendant. If your complaint today is a headache, he will act on that headache. ECU does not investigate any type of disease. (G-FHS).

ECU doctors reinforce that, in addition to looking more focused on symptoms, excess demand reduces the time available for contact with users: "My contact with the user is minimal, I have to be extremely fast, I expose myself more to the error because I have to attend a lot of people very quickly" (PS-ECU). There is often insecurity and risk for the professional: "We end up not paying attention to the user when he is not at risk at the moment" (PS-ECU).

The speed of service is also negatively perceived by the user:

Here they look like they are the genie. (ECU).

They look at you and say: this is a virus, they don't even put their hands on us to say that we have it. (U).

The service at the ECU was criticized by users due to the risk classification and the delay in service: "Because sometimes you arrive and there is no doctor, then you have to wait 4, 5 hours. Others pass by, and you get worse than when you arrived" (U).
The ECU manager identified as a difficulty serving FHS users from other territories:

Difficulty is when I receive a user from another territory who I'm going to refer to his territory and he says that it's no use sending him to the family clinic because it doesn't work there and as he was well attended here, so he starts to want to solve his problem here. (G-ECU).

The ECU's referral to the FHS burdens the territory's clinic because users not covered by the FHS understand that the clinic next door should receive it:

The ECU guides the user to look for the family clinic, but they do not explain that it has to be where the person lives. So we [from FHS] end up assisting the user so that he is not harmed. (G-FHS).

The inadequate qualification of the FHS physicians was identified as a difficulty by an ECU manager: "The difficulty in attending to urgency and emergency services in the FHS is the qualification of the physician" (G-ECU). Although the perception of low qualification was an isolated report, this understanding is negative considering that the integration between the services needs the support of the managers involved. The insufficient technical qualification of the PHC physician had already been pointed out by ECU physicians ${ }^{4}$.

FHS's gateway is seen as unsatisfactory. Despite being an attribution of everyone, only the ACS mostly assume the role of reception. Furthermore, this is an issue that generates a lot of dissatisfaction among these professionals: "And when it says that the reception of the users is for the whole team, they only see the ACS" (ACS).

The responsibility for welcoming causes insecurity in the ACS to act in the identification of risks: "The fear of all health agents is to deal with emergencies. Because it gives insecurity" (ACS).

There was a complaint from the user about the accreditation system: 
Because I never got treatment at the clinic. Every time I came to get the file, they said: wait, the Health Agent will come to your house. The Health Agent has not discovered my house until today. So I particularly prefer the ECU. (U).
Bad experiences with care at any of the health facilities define the user's choice.

Next, a summary table of the analysis of the categories will be presented, representing the qualitative content of the results, by professional category and location.

Table 3. Analysis of categories by type of respondent and service of origin

\begin{tabular}{|c|c|c|c|c|c|}
\hline \multirow[b]{2}{*}{ Categories } & \multicolumn{2}{|l|}{ FHS } & \multicolumn{2}{|l|}{ ECU } & \multirow[b]{2}{*}{ USERS } \\
\hline & Managers & Professionals & Managers & Professionals & \\
\hline $\begin{array}{l}\text { WHICH EMER- } \\
\text { GENCY FOR } \\
\text { WHICH SER- } \\
\text { VICE }\end{array}$ & Adequate concept & $\begin{array}{l}\text { Adequate concept, } \\
\text { without unanimity }\end{array}$ & Adequate concept & $\begin{array}{l}\text { Adequate con- } \\
\text { cept, without } \\
\text { unanimity }\end{array}$ & $\begin{array}{l}\text { Adequate concept, without una- } \\
\text { nimity, but previous experience in } \\
\text { services is crucial for the choice. }\end{array}$ \\
\hline $\begin{array}{l}\text { TERRITORIAL } \\
\text { ISSUES }\end{array}$ & $\begin{array}{l}\text { Recognizes that the social } \\
\text { fragility of the territory } \\
\text { produces demands. }\end{array}$ & $\begin{array}{l}\text { The social fragility } \\
\text { of the territory is } \\
\text { enhanced by the } \\
\text { affiliation of a larger } \\
\text { clientele than in } \\
\text { other systems. }\end{array}$ & $\begin{array}{l}\text { Social fragility disqualifies the } \\
\text { user. }\end{array}$ & $\begin{array}{l}\text { Violence in the } \\
\text { territory harms } \\
\text { not only the resi- } \\
\text { dent population, } \\
\text { but also the flow } \\
\text { of work. }\end{array}$ & $\begin{array}{l}\text { The socio-environmental condi- } \\
\text { tions of the territory did not } \\
\text { appear as an issue brought up by } \\
\text { the population, but their interfer- } \\
\text { ence with care was evident. }\end{array}$ \\
\hline ACCESS & $\begin{array}{l}\text { There is doubt whether } \\
\text { the professional meets } \\
\text { spontaneous demand } \\
\text { throughout the day. } \\
\text { Regrets that the hos- } \\
\text { pitalization demand is } \\
\text { directed to the ECU, not } \\
\text { the hospital. } \\
\text { Priority access to the } \\
\text { local ECU vacancy is } \\
\text { positive. }\end{array}$ & $\begin{array}{l}\text { Spontaneous de- } \\
\text { mand strains the } \\
\text { quality of care and } \\
\text { actions of health } \\
\text { prevention and } \\
\text { promotion. }\end{array}$ & $\begin{array}{l}\text { The user overuses the UPA. } \\
\text { The main problem is the lack of } \\
\text { access to the hospital bed. }\end{array}$ & $\begin{array}{l}\text { They complain } \\
\text { about low risk } \\
\text { excess demand. }\end{array}$ & $\begin{array}{l}\text { They understand that they have } \\
\text { the right to use the service that is } \\
\text { most convenient for them. } \\
\text { Complain about the referral to } \\
\text { the FHS } \\
\text { Possible pilgrimage for services. }\end{array}$ \\
\hline $\begin{array}{l}\text { POSITIVE } \\
\text { ASPECTS }\end{array}$ & $\begin{array}{l}\text { The link with the popula- } \\
\text { tion and the proximity of } \\
\text { a ECU in the territory. }\end{array}$ & $\begin{array}{l}\text { The clinical follow- } \\
\text { up that produces } \\
\text { quality. }\end{array}$ & $\begin{array}{l}\text { Physician training and material } \\
\text { and technological resources } \\
\text { Interaction with the local FHS. }\end{array}$ & $\begin{array}{l}\text { Physician train- } \\
\text { ing and material } \\
\text { and technological } \\
\text { resources }\end{array}$ & $\begin{array}{l}\text { Respect and affection in the care } \\
\text { provided by the FHS. }\end{array}$ \\
\hline $\begin{array}{l}\text { NEGATIVE } \\
\text { ASPECTS }\end{array}$ & $\begin{array}{l}\text { O desfinanciamento e } \\
\text { o contexto adverso da } \\
\text { atenção à saúde. } \\
\text { O atendimento centrado } \\
\text { na queixa. } \\
\text { Acomodação de deman- } \\
\text { das espontânea e pro- } \\
\text { gramada. } \\
\text { Atender usuários de } \\
\text { outros territórios da FHS, } \\
\text { encaminhados pela ECU. }\end{array}$ & $\begin{array}{l}\text { Excessive spontane- } \\
\text { ous demand, which } \\
\text { interferes with the } \\
\text { quality of service to } \\
\text { scheduled demand. } \\
\text { The gateway under } \\
\text { the responsibility } \\
\text { of the ACS, which } \\
\text { creates insecurity } \\
\text { for themselves. }\end{array}$ & $\begin{array}{l}\text { Underfunding and the adverse } \\
\text { context of health care. } \\
\text { Complaint-centered care. } \\
\text { Insufficient qualification of FHS } \\
\text { physicians to attend to emergen- } \\
\text { cies. } \\
\text { Difficulty in serving users from } \\
\text { other territories. } \\
\text { The closure of the FHS during } \\
\text { the shootings, which burdens } \\
\text { the ECU. }\end{array}$ & $\begin{array}{l}\text { Excessive de- } \\
\text { mand interferes } \\
\text { with the quality of } \\
\text { care and creates } \\
\text { risks for the pro- } \\
\text { fessional. }\end{array}$ & $\begin{array}{l}\text { Speed during service at the ECU. } \\
\text { Long wait for ECU service. } \\
\text { Risk classification in the ECU. } \\
\text { Difficulty in being registered with } \\
\text { FHS. }\end{array}$ \\
\hline
\end{tabular}




\section{Discussion}

The focus on DE care for low-risk emergencies and the incorporation of the vision of different actors provided the analysis, albeit partial, of the care given in an area of high socio-environmental vulnerability.

From the production data, it can be stated that the local FHS takes on the role of attending to emergencies, being responsible for $82.4 \%$ of the total demand. This suggests an advance in relation to previous studies, which pointed out the non-implementation of this service ${ }^{2,3}$. The population coverage assigned to the teams constitutes a challenge for the mission of prompt assistance at $\mathrm{PHC}^{2}$. In addition, it is difficult to access the FHS for low-risk emergency care through $\mathrm{DE}$, as well as to offer programmatic actions, of health prevention and promotion, despite the effort for reconciling various activities ${ }^{10}$, especially in highly vulnerable territories, such as the studied.

Advanced access - one of the ways to manage demand that favors same-day service - has the potential to reduce users' waiting time for appointments. Same-day care increases user satisfaction and reduces absenteeism from DP appointments. However, there is no robust scientific evidence that advanced access translates into better health outcomes ${ }^{11}$. Furthermore, there is a risk that advanced access will reduce the continuity of care, affecting the monitoring of patients with chronic conditions, who need regular scheduled appointments?

The FHS attended a higher percentage of elderly people than the ECU, which can mean a bond and adherence to the PHC. However, the expressive percentage of visits to children in the ECU - which, at the time, had no pediatrician - may represent resistance or inadequacy of the local population to this loss.

In contrast to a study, in which the female gender was more prevalent ${ }^{\mathbf{1 2}}$, in ECU, there was no significant difference in relation to gender. In FHS, the service to females was predominant ${ }^{\mathbf{1 3}, \mathbf{1 4}}$ for unspecified reasons, but which must be related to the culture of attending the units for women's and children's health programs, with the working hours of the units, for reasons of insertion in the labor market, among others. In addition, men's resistance to seeking primary care must be taken into account, which was the reason for the creation of the National Policy for Comprehensive Attention to Men's Health.

In the PHC clinic, the diversity of diagnoses was greater than in the ECU, with a predominance of infectious and parasitic, endocrine and metabolic diseases, and diseases of the circulatory system. Similar to what was found in this study, there was a predominance of low back pain and musculoskeletal disorders, followed by infectious diseases in the care provided at the ECU 15,16 .

The high number of unspecified ICD records in the ECU seems to indicate a focus on identifying symptoms, without privileging a precise diagnosis, despite the urgency policy recommending more integrated care for the ECU and less focused on complaints/ conduct $^{17}$. Consistently, however, with the urgency policy, the ECU managers identified the complaint centered service as a negative point; at the same time, ECU professionals reported fearing the increased risk of errors, resulting from the speed of service due to excess demand.

The speed of service is also seen negatively by ECU users. One of them jokingly suggested that the doctors are 'genies in the lamp', clearly pointing to consultations without physical examination, which goes against the urgency policy and good clinical practices.

The measurement of waiting times was not possible due to lack of records; but, as a result of the observation of the services, there was a wait for medical care that reached three hours - which does not conflict with the literature that reports that, only 'in most cases', this time does not exceed two hours -, the waiting time being even higher in the ECU ${ }^{13}$. The absence of a medical professional at FHS - even if justified 
by the performance of other activities - generates conflicts. In this sense, it is important to note that there was a strike that caused a reduction in the capacity for care during the study period.

Recognizing the patient's perspective is important for the professionals' understanding of the demands. However, it does not change the negative feeling of ECU professionals about caring for the majority of green patients, largely mentioned in the literature in national ${ }^{3,15}$, as well as local ${ }^{12,13,17}$ studies.

The search for emergency services may result from the users' personal experiences, from self-perception about the severity of the disease, for convenience and/or belief in greater resolvability of this type of service ${ }^{\mathbf{1 2}}$. Managers and practitioners understand that low-risk urgency must be incorporated into the PHC. Few professionals still believe that the $\mathrm{PHC}$ is not a place for urgency, like some ACS. Authors indicate that PHC with a work process based on routine care creates gaps that do not allow for a comprehensive gateway ${ }^{\mathbf{1 8}}$, which welcomes urgent demands.

Users recognize the $\mathrm{PHC}$ as a place of immediate assistance, as in another area of the municipality with an ECU integrated to the $\mathrm{PHC}^{16}$. The choice of the ECU depends on its severity and the assessment that the PHC will not solve the user's problem ${ }^{13}$. Users, despite practicing a good use of different services, use their experience as a definition of choices.

The territory is a producer of mobilization and demands ${ }^{19}$. Territorialization, in the FHS scenario, also in the present study, remains a major challenge to be faced in daily life, as it combines spaces of power, social determinants of the health-disease-care process and social equipment ${ }^{20}$. The still high number of people served by the team and the high social vulnerability make the work of teams more complex ${ }^{\mathbf{1 0}}$.

The experience of managers and professionals showed that demand is strongly influenced by poverty and socio-environmental weaknesses. The FHS proved to be more sensitive to social issues, made invisible in other contexts ${ }^{\mathbf{1 4}}$. There was dissatisfaction among ECU professionals with the closing of the PHC during shootings, which occurred frequently in the territory studied in Rio de Janeiro ${ }^{10}$.

Access is a structural component for obtaining care at $\mathrm{PHC}^{21}$. To be a care coordinator, the PHC needs to be integrated into a network $\mathbf{1}$. Greater service capacity was identified at the PHC, with the ECU as a backup, in addition to synchrony between services ${ }^{16}$.

ECU managers trust the local FHS more than the PHC in other territories. However, doubts persist about the technical quality in attending to emergencies in $\mathrm{FHS}^{22}$.

From the point of view of professionals working at FHS, welcoming the patient by a team was a valued point, as strengthened bonds provide power to understand the demands ${ }^{23}$.

Despite the benefit of the bond, there is a question about the first contact in the service being under the responsibility of the ACS, even with the support of the nursing team. FHS teams assess risks and vulnerabilities according to their knowledge and practical experience, which legitimizes the feeling of insecurity. There is an absence of a risk as-

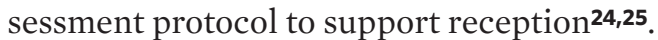

Another issue that mobilized the interviewees was the permanence in the ECU of patients with indication for hospitalization by the FHS, characterizing difficulty in accessing the hospital bed. This local concern with hospitalization in ECU has already been evidenced in the city of Rio de Janeiro ${ }^{22}$, a fact that is characterized as a national phenomenon ${ }^{3}$.

The current health crisis in the city was firmly pointed out by managers as an important obstacle to the quality of care. Since 2016, there has been a decrease in municipal revenue for 'Public Health Actions and Services', as well as an increase in the number of FHS teams without doctors and a significant decrease in beds available for regulation, highlighting health as a low priority for the municipal management ${ }^{26}$. 


\section{Final considerations}

The proximity between the ECU and the PHC can be an element that produces integration between the services. In addition to interacting well and with a reasonable level of trust, integration becomes more important given the difficulty of accessing the hospital bed.

There was an appropriation by the FHS of its role of attending to small emergencies and of the complementarity of the ECU. However, the compatibility between DE and DP appears as a major obstacle, despite the strategies for actions of health prevention and promotion.

Social fragility produces demands, and the FHS was more powerful in meeting them than the ECU. The fragility of the population's employment relationships corroborates the standard of care centered on urgency, due to which the user is unable to adhere to the PHC.

Access, even if positive, is still constrained by long waiting times for assistance. A limitation of this study was that it was not able to measure this waiting time due to unavailability of information.

The population's level of satisfaction with the FHS was significant. The fact that there was a strike during the research showed that the FHS professionals, who were part of this study, spoke with the population about the crisis in the health area.

The centrality of the PHC for assistance networks is enhanced by the reception of emergency situations, especially if there is, as in this case, a complementary relationship with the ECU.

Some strategies can contribute to integrate services such as a single management, shared information system and providing opportunities for professionals, as a form of training, to monitor the work between the units.

\section{Collaborators}

Constantino LR (0000-0002-2363-5557)* and O'Dwyer G (0000-0003-0222-1205)* contributed to the design, research, writing and review of the article. Santos VLB (00000002-6167-9833)* contributed to the research and writing of the article. Seta $\mathrm{MH}$ (00000003-4764-5159)* contributed to the design of the research and writing of the article. 


\section{References}

1. Bousquat A, Giovanella L, Fausto MCR, et al. Tipologia da estrutura das unidades básicas de saúde brasileiras: os 5 R. Cad. Saúde Pública. 2 017; 33(8):e00037316

2. Soares SS, Lima LD, Castro ALB. O papel da Atenção Básica no atendimento às urgências: um olhar sobre as políticas. Manag Prim Health Care. 2014; 5(2):170177.

3. O’Dwyer G, Konder MT, Reciputt LP, et al. O processo de implantação das unidades de pronto atendimento no Brasil. Rev. Saúde Pública. 2017; 51(125).

4. Konder MT, O'Dwyer G. A integração das Unidades de Pronto Atendimento (UPA) com a rede assistencial no município do Rio de Janeiro, Brasil. Interface. $2016 ; 20(59): 879-892$.

5. Alves HPF. Vulnerabilidade socioambiental na metrópole paulistana: uma análise sociodemográfica das situações de sobreposição espacial de problemas e riscos sociais e ambientais. 2006. Rev. Bras. Estud. População. 2006; 23(1)43-59.

6. Denzin N, Lincoln Y. Handbook of qualitative research. Thousand Oaks: Sage; 2000.

7. Junior WC, Torres BLB, Rausch MCP. Sistema Manchester de Classificação de Risco: comparando modelos. [acesso em 2021 fev 2]. Disponível em: https:// docplayer.com.br/15263026-Sistema-manchester-de-classificacao-de-risco-comparando-modelos-welfane-cordeiro-junior-barbara-lopes-de-brito-torres-maria-do-carmo-paixao-rausch.html.

8. Deslandes SF. Revisitando as Metodologias Qualitativas nas Pesquisas de Avaliação: vertentes, contribuições e desafios. In: Baptista TWF, Azevedo CS, Machado CV, organizadoras. Políticas, planejamento e gestão em saúde: abordagens e métodos de pesquisa. Rio de Janeiro: Editora Fiocruz; 2015. p. 193-217.

9. Rose KD, Ross JS, Horwitz LI. Advanced Access Scheduling Outcomes: A Systematic Review. Arch Intern Med. 2011; 171(13):1150-1159.
10. Neto GCC, Antunes VH, Oliveira A. A prática da Medicina de Família e Comunidade no Brasil: contexto e perspectivas. Cad. Saúde Pública. 2019; 35(1).

11. Camargo DS, Castanheira ERL. Ampliando o acesso: o Acolhimento por Equipe como estratégia de gestão da demanda na Atenção Primária à Saúde (APS). Interface. 2020 [acesso em 2021 fev 2]; 24(supl1):e190600. Disponível em: https://doi.org/10.1590/Interface.190600.

12. Godoi VCG, Ganassin GS, Inove KC, et al. Acolhimento com classificação de risco: caracterização da demanda em unidade de pronto atendimento. Cogitare Enfer. 2016; 21(3):1-8.

13. Pires MRGM, Göttems LBD, Cupertino TV, et al. A Utilização dos Serviços de Atenção Básica e de Urgência no SUS de Belo Horizonte: problema de saúde, procedimentos e escolha dos serviços. Saúde Soc. 2013; 22(1):211-223.

14. Ribeiro LA, Scatena JHG. Avaliação da qualidade da Estratégia de Saúde da Família em um município de porte médio. Saúde debate. 2019; 43(7):126-140.

15. Conselho Nacional de Secretários de Saúde. Rede de Atenção às Urgências e Emergências: avaliação da implantação e do desempenho das Unidades de Pronto Atendimentos (UPAs). Brasília, DF: CONASS; 2015 (CONASS Documenta, 28). [acesso em $2021 \mathrm{fev}$ 2]. Disponível em: http://www.conass.org.br/biblioteca/pdf/Conass_Documenta_28.pdf.

16. Soares SS. Desigualdade e Dupla porta de entrada no território: desafios para organização da atenção às urgências de baixo risco no município do Rio de Janeiro. [dissertação]. Rio de Janeiro: Escola Nacional de Saúde Pública Sergio Arouca, Fundação Oswaldo Cruz; 2017. 95 p.

17. Konder MT, O’Dwyer G. As Unidades de Pronto-Atendimento na Política Nacional de Atenção às Urgências. Physis: Rev de Saúde Colet. 2015; 25(2):525-545. 
18. Silva AS, Fracolli LA. Avaliação da Estratégia Saú-de da Família: perspectiva dos usuários em Minas Gerais, Brasil. Saúde debate. 2014; 38(103):692-705.

19. Machado FRS, Guizardi FL, Lemos ASP. A burocracia cordial: a implantação da estratégia de apoio institucional na política nacional de atenção básica em saúde. Trab. educ. saúde. 2019; 17(3):e0022151.

20. Lima CA, Moreira KS, Costa GS, et al. Avaliação do processo de trabalho entre equipes de saúde da família de um município de Minas Gerais, Brasil. Trab. Educ. Saúde. 2019; 17(1):e0018710.

21. Cunha ABO, Vieira-da-Silva LM. Acessibilidade aos serviços de saúde em um município do Estado da Bahia, Brasil, em gestão plena do sistema. Cad. Saúde Pública. 2010; 26(4):725-737.

22. Konder MT, O’Dwyer G. As Unidade de Pronto Atendimento como unidades de internação: fenômenos do fluxo assistencial na rede de urgências. Physis: Rev Saúde Colet. 2019; 29(2).
23. Norman AH, Tesser CD. Acesso ao cuidado na Estratégia Saúde da Família: equilíbrio entre demanda espontânea e prevenção/promoção da saúde. Saúde Soc. $2015 ; 24(1): 165-179$.

24. Faria RC, Campos EMS. Demanda Espontânea na Estratégia de Saúde da Família: uma análise dos fatores que a influenciam e os desafios na reorientação do modelo assistencial do SUS. Revista de APS 2012; 15(2):148-157.

25. Vieira EW, Gazzinelli A. Grau de integração da Atenção Primária à Saúde de município de pequeno porte na Rede de Atenção à Saúde. Saúde Soc. 2017; 26(2):448-462.

26. O’Dwyer G, Graever L, Britto FA, et. al. A Crise e a Saúde: Implicações para a Política, a Gestão e o Cuidado. Ciênc. Saúde Colet. 2019; 24(12):25.

Received on $07 / 24 / 2020$

Approved on 04/20/2021

Conflict of interests: non-existent

Financial support: Teias Manguinhos research. ENSP-043PPE-14-2-4 